Research Article

\title{
Comprehensive Risk Assessment of Health-Related Hazardous Events in the Drinking Water Supply System from Source to Tap in Gaza Strip, Palestine
}

\author{
Samer Abuzerr, ${ }^{1,2,3}$ Mahdi Hadi, ${ }^{4}$ Kate Zinszer, ${ }^{2}$ Simin Nasseri $\mathbb{D}^{0},{ }^{4,5}$ Masud Yunesian $\mathbb{D},{ }^{5,6}$ \\ Amir Hossein Mahvi, ${ }^{4,5}$ Ramin Nabizadeh, ${ }^{5}$ and Shimels Hussien Mohammed ${ }^{7}$ \\ ${ }^{1}$ Department of Environmental Health Engineering, School of Public Health, International Campus, \\ Tehran University of Medical Sciences, Tehran, Iran \\ ${ }^{2}$ School of Public Health, Department of Social and Preventive Medicine, University of Montreal, Montréal, Canada \\ ${ }^{3}$ Quality Improvement and Infection Control Unit, Ministry of Health, Gaza, State of Palestine \\ ${ }^{4}$ Center for Water Quality Research (CWQR), Institute for Environmental Research (IER), Tehran University of Medical Sciences, \\ Tehran, Iran \\ ${ }^{5}$ Department of Environmental Health Engineering, School of Public Health, Tehran University of Medical Sciences, Tehran, Iran \\ ${ }^{6}$ Department of Research Methodology and Data Analysis, Institute for Environmental Research, TUMS, Tehran, Iran \\ ${ }^{7}$ Department of Community Nutrition, School of Nutritional Sciences and Dietetics, Tehran University of Medical Sciences, \\ Tehran, Iran
}

Correspondence should be addressed to Simin Nasseri; naserise@tums.ac.ir

Received 26 March 2019; Accepted 13 December 2019; Published 29 January 2020

Academic Editor: Issam A. Al-Khatib

Copyright ( $) 2020$ Samer Abuzerr et al. This is an open access article distributed under the Creative Commons Attribution License, which permits unrestricted use, distribution, and reproduction in any medium, provided the original work is properly cited.

Background. The traditional approach in the management of the quality drinking water, and relying on end-product testing, has proven ineffective in protecting public health. Therefore, the transition to a systematic approach in drinking water supply systems management from the source to the consumer tap was taken as a water safety plan (WSP). Objective. The study aims to investigate the health-related hazardous events in order to decide on the best risk-reduction strategies in the supply of drinking water in the Gaza strip. Methods. A semiquantitative matrix method for risk assessment was applied. Also, chlorine residual, electrical conductivity, and nitrate concentration further tested in 109 water wells, 109 small-scale water desalination plants, 197 tanker trucks, and 384 households distributed over five governorates of the Gaza strip. Results. The mean of the measured chlorine residual values was less than the recommended national and international limits $(0.2-1 \mathrm{mg} / \mathrm{liter})$. The mean of electrical conductivity at catchment points and household municipal water taps was $2165.1 \mu \mathrm{S} \cdot \mathrm{cm}^{-1}$ and $2000 \mu \mathrm{S} \cdot \mathrm{cm}^{-1}$, respectively. Furthermore, zero percent of water samples met the recommended criteria, indicating that the groundwater in the Gaza strip is nonpotable. Only $12.8 \%$ and $8.8 \%$ of water samples met the permissible levels at catchment areas and municipal water at household, respectively, indicating sever health impacts on the public. Moreover, the most hazardous events were related to high levels of groundwater salinity, the low level of disinfection, the effect of electricity outages on the efficiency of the desalination process, and leakage of water from the tanker truck tank reservoirs. Therefore, urgent interventions are required to improve the quality of water and to mitigate the possible health effects. Conclusion. The prioritization of hazardous events that are proportional to the degree of their attributed risk could help guide in making the right risk-reduction decisions. Urgent interventions are required to improve the quality of water and to mitigate the possible health effects. 


\section{Introduction}

Possessing safe drinking water is crucial for the development of sustainable health and a booming economy for any society $[1,2]$. Despite the efforts of drinking water supply agencies around the world to provide safe drinking water, waterborne diseases cause 2.4 million deaths and 73 million disabilityadjusted life years (DALYs) [3, 4]. Furthermore, natural and anthropogenic threats to the drinking water supply systems (DWSS) in urban areas lead to adverse human health outcomes $[5,6]$. Therefore, the full control of the drinking water supply systems considering the surrounding environmental factors has a vital role in reducing the risk of potential contamination [7].

The conventional approach of water supply management, relying on end-product testing, has proven to be ineffective in protecting public health and the quality of drinking water. Hence, a transition to an integrated risk management approach for the management of DWSS from the catchment to the consumer tap was adopted at the beginning of 2004 [8]. The water safety plan (WSP) was introduced in the third edition of the World Health Organization's guidelines for drinking water quality (GDWQ) as a useful tool to systematically assess and manage risks in DWSSs from source to consumption point [1, 9-11].

More recently, in the WSP workshop in Berlin in 2014 for the assurance provision of safe drinking water to citizens in the twenty-first century, the WSP also was approved as a systematic and valuable managerial tool [12]. Moreover, several countries have been welcomed the adoption of the WSP as national legislation to achieve outstanding successes in managing DWSSs [9, 13-15].

The applied risk assessment approach in this study was relied on using a semiquantitative matrix method. In this approach, the risk was quantified based on the probability of hazardous events occurrence (due to exposure with biological, physical, chemical, or radiological agents) and the severity of their consequences on the DWSSs [16, 17].

DWSSs in the Gaza strip, as in developing countries, are vulnerable to different kinds of hazards. The deterioration of groundwater quality, the only source of water in the Gaza strip, has prompted the establishment of brackish water small-scale desalination plants as a strategic solution to meet the community needs for potable water. Nowadays, the vast majority of Gaza's population relies on desalinated water, mainly for drinking purposes. However, the problems related to water quality due to the presence of microbial, chemical, and physical agents have been reported in Gaza's DWSSs, primarily due to the nonhygienic practices during water transportation or storage [18-22]. Moreover, we underline the fragile state of coordination among institutions in charge of the water sector in the Gaza strip [23].

To the best of our knowledge, this is the first study that provided an overarching description of most critical hazardous events in drinking water supply systems from source to tap in the Gaza strip in order to enable water supply providers and stakeholders to decide on the best risk-reduction strategies.

\section{Materials and Methods}

2.1. Study Setting. The current study was conducted in the Gaza strip between March 2018 and July 2018. This region is the southwestern corner of Palestine with an area of around $365 \mathrm{~km}^{2}$. It shares borders with the lands of historical Palestine (so-called Israel now) to the east and north, Egypt to the south, and the Mediterranean Sea to the west. Its population was estimated at 1,912,267 inhabitants distributed over five governorates with high population density at 5,324 persons $/ \mathrm{km}^{2}$ (Figure 1) [24].

2.2. Study Design and Sampling. An observational study was carried out from March 2018 to July 2018 to identify the hazardous events in each part of a typical drinking water supply system in the Gaza strip, including water wells, desalination plants, tanker trucks, and municipal water and desalinated water at households. It is worth mentioning that there are two water supply systems in the Gaza strip. The first is for nondesalinated municipal water for domestic purposes, whereas the second is for desalinated water for drinking purposes (Figure 2).

More than 150 small-scale brackish desalination plants exist along the Gaza strip in order to improve the quality of groundwater [20]. A cluster sampling was adopted in our study, as the study sample was distributed into five governorates based on the population density in each governorate.

Seven experts in the fields of water resource management, environmental health, and public health were recruited as WSP team members. They underwent a five-day training to enable them define and identify adequately the likelihood of occurrence and severity of each hazardous event and avoid subjective assessment during field visits. The training package is inspired by the "Drinking Water Safety Plan Training Course," which is sponsored by Alberta Environment and Sustainable Resource Development. The training was offered by the study authors [25].

The WSP team members joined the field visits together, and each of them reported the likelihood of occurrence and severity of each hazardous event individually on his datasheet, and then, the average of the reported likelihoods and severity values was considered.

Hazards in this study refer to biological, chemical, and physical agents. Approximately 109 water wells, 109 smallscale water desalination plants, 197 tanker trucks, and 384 households were included in this study.

\subsection{Study Tools}

2.3.1. Water Testing. Three field-based chemical water quality tests including residual chlorine, electrical conductivity, and nitrate ions level were tested. The tests were conducted in triplicates, and the mean values were recorded. The residual chlorine was measured according to the standard colorimetric method using the $\mathrm{N}, \mathrm{N}^{\prime}$-diethyl-pphenylenediamine (DPD) reagent [26]. 


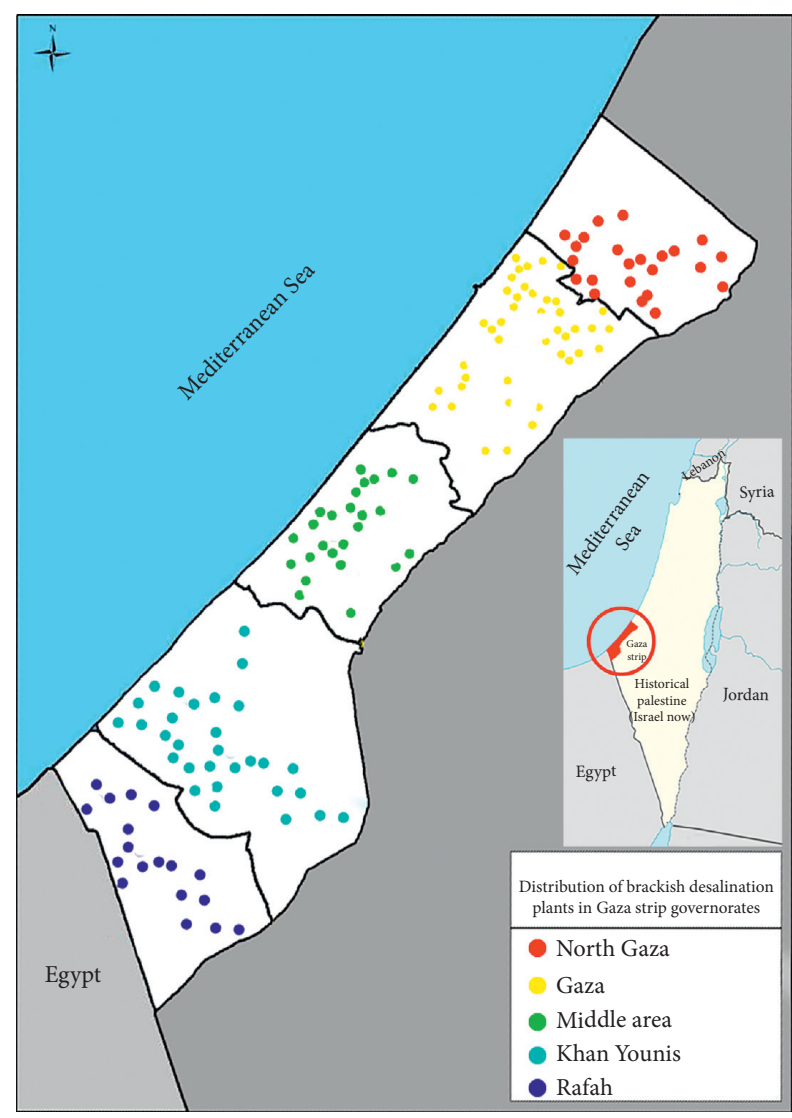

FIGURE 1: Gaza strip map and distribution of small-scale water desalination plants in the five governorates.

Electrical conductivity was measured using a portable instrument called a DDS 307 conductivity meter. Nitrate was measured by aquaread nitrate meter for water testing [27].

2.3.2. Risk Matrix. A matrix of five rows and five columns was used as an instrument for observation and assessment. The columns represent the degree of likelihood of the hazard occurrence, whereas the rows denote the severity of the hazard occurring. Each hazardous event was rated individually and after that combined into an overall risk score [16].

Value for the likelihood of the occurrence of each undesirable event is defined in Table 1 [1]. The risk matrix of the catchment, small-scale desalination plant, tanker trucks, and households included 14, 20, 18, and 18 potential hazardous events, respectively.

2.4. Hazardous Events Identification. The hazardous events of each risk matrix were developed after reviewing the relevant scientific and technical information to match with the local context of each drinking water supply system in the Gaza strip. The WSP team independently validated the final draft of the matrix.

2.5. Sample Size Determination. The study population comprised 260 municipal water wells, 150 small-scale brackish desalination plants, 400 tanker trucks, and 303,330 households distributed over the five governorates of the Gaza strip. The sample size was calculated using Epi Info program with a margin of error of $5 \%$, confidence level of $95 \%$, and a response distribution of $50 \%$. Hence, the calculated sample size was 109 municipal water wells, 109 small-scale brackish desalination plants, 197 tanker trucks, and 384 households.

2.6. Data Analysis. Each completed matrix was manually checked in order to ensure the quality of the collected data in the matter of completeness, clarity, and uniformity before it could be coded in MS Excel 2007. The mean, standard deviation, minimum, maximum, and percentage of samples that met the recommended limits were calculated for the readings of chlorine residual, electrical conductivity, and nitrate throughout the DWSSs.

The average and standard deviation were calculated as well as for the likelihood, severity, and degree of risk for each hazardous event.

\section{Results}

3.1. Water Chemistry Parameters. Interestingly, the mean of the measured chlorine residual values in DWSSs was less than the recommended limits of both Palestinian water authority (PWA) and world health organization (WHO) (0.2-1 mg/liter). We found decreased residual chlorine levels in both catchment areas and the households. The following are the percentage values of the various sites that met the recommended chlorine residual criteria: catchment areas $31.2 \%$, treatment plants $18.3 \%$, tanker trucks $14.7 \%$, desalinated water at households $4.3 \%$, and municipal water for households $30.2 \%$. A marked decrease in electrical conductivity before and after the desalination process was recorded. The mean of electrical conductivity at catchment points and at household municipal water taps was $2165.1 \mu \mathrm{S} \cdot \mathrm{cm}^{-1}$ and $2000 \mu \mathrm{S} \cdot \mathrm{cm}^{-1}$, respectively.

Furthermore, zero percent of water samples met the recommended criteria $(250 \mu \mathrm{S} / \mathrm{cm})$, indicating that the groundwater in Gaza strip is nonpotable water and generally contains a high level of dissolved solids. Despite acceptable nitrate levels in the desalinated water, high levels of nitrates were recorded in the DWSSs, and only $12.8 \%$ and $8.8 \%$ of water samples met the PWA and WHO permissible levels (70 and $50 \mathrm{mg} / \mathrm{L}$, respectively) at the catchment areas and municipal water at households, respectively, indicating severe health impacts on public health (Table 2).

3.2. Assessment of Hazardous Events. The assessment of health-threatening hazardous events in DWSSs using inspection forms helps in providing a comprehensive and integrated understanding of risks and their control measures [28]. Risk characterization was provided in the context of the multiple-barrier approaches, so it categorizes each hazard by its associated barrier. For instance, a pipeline leakage is a hazardous event associated with the water distribution system and maintenance barrier. Consequently, linking risks 


\section{Water supply in the Gaza Strip}

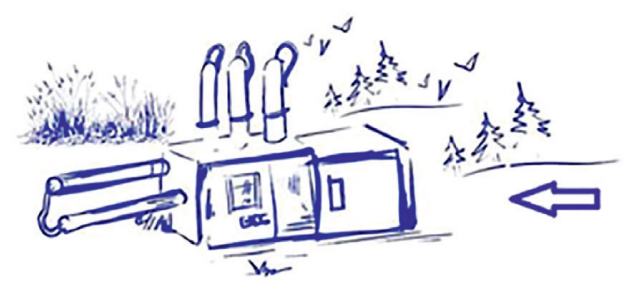

109 Brackish water desalination plants (treatment)

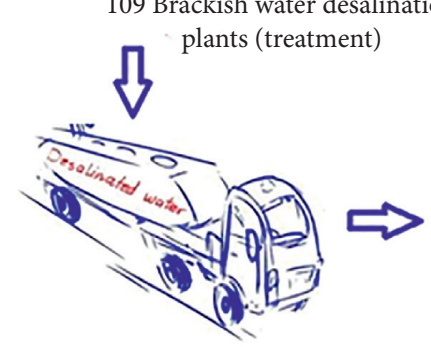

197 Tanker trucks

(Distribution)

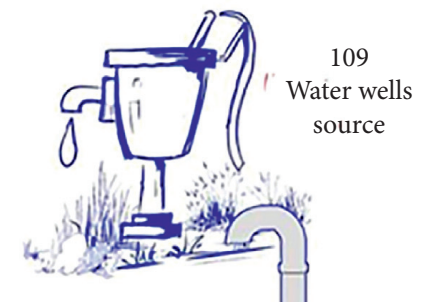

Municipal water net work for domestic uses (metallic or plastic pipes)

FIGURE 2: Schematic illustration map of a typical Gaza strip's water supply systems.

TABLE 1: Semiquantitative risk analysis matrix.

\begin{tabular}{|c|c|c|c|c|c|c|}
\hline & \multicolumn{5}{|c|}{ Severity } \\
\hline & & $\begin{array}{c}\text { Insignificant or } \\
\text { no } \\
\text { impact-rating: } \\
1\end{array}$ & $\begin{array}{c}\text { Minor } \\
\text { compliance } \\
\text { impact-rating: } \\
2\end{array}$ & $\begin{array}{c}\text { Moderate } \\
\text { aesthetic } \\
\text { impact_rating: } \\
3\end{array}$ & $\begin{array}{c}\text { Major regulatory } \\
\text { impact_rating: } \\
4\end{array}$ & $\begin{array}{c}\text { Catastrophic } \\
\text { public } \\
\text { health } \\
\text { impact-rating: } 5\end{array}$ \\
\hline \multirow{5}{*}{$\begin{array}{l}\text { Likelihood } \\
\text { or } \\
\text { frequency }\end{array}$} & $\begin{array}{c}\text { Almost certain/once a } \\
\text { day_rating: } 5\end{array}$ & 5 & 10 & 15 & 20 & 25 \\
\hline & $\begin{array}{l}\text { Likely/once a week-rating: } \\
44\end{array}$ & 4 & 8 & 12 & 16 & 20 \\
\hline & $\begin{array}{l}\text { Moderate/once a } \\
\text { month—rating: } 3\end{array}$ & 3 & 6 & 9 & 12 & 15 \\
\hline & $\begin{array}{l}\text { Unlikely/once a } \\
\text { year-rating: } 2\end{array}$ & 2 & 4 & 6 & 8 & 10 \\
\hline & $\begin{array}{l}\text { Rare/once every } 5 \\
\text { years-rating: } 1\end{array}$ & 1 & 2 & 3 & 4 & 5 \\
\hline Risk score & & $<6$ & 6-9 & & -15 & $>15$ \\
\hline Risk rating & & Low & Medium & & gh & Very high \\
\hline
\end{tabular}

to barriers facilitates an analysis of the effectiveness and reliability of protective barriers. The hazardous events were arranged in descending order according to the calculated degree of risk for each hazardous event in DWSSs.

3.2.1. Catchment Points. At water storage tanks of abstracted groundwater, the high level of salinity of groundwater had the highest degree of risk, followed by excessive algal formations. However, nine hazardous events were found to cause a medium degree of risk, whereas two hazardous events formed a low degree of risk (Table 3).

3.2.2. Production Points. At brackish small-scale desalination plants, the highest degree of risk was due to the low level of chlorination and because of the effect of power outages on the efficiency of the desalination process. One hazardous event was found to cause a medium degree of risk, which is the mixing of desalinated water with nondesalinated water in water storage tanks. Nevertheless, the rest of the hazardous events constituted a low degree of risk (Table 4).

3.2.3. Transportation Points. Tanker trucks posed a very high degree of risk caused by the low level of disinfection, the excessive algal formations inside the tanker truck reservoir, and leakage of water. Whereas a medium degree of risk as a result of lack of tanker truck license by the Ministry of Health and the absence of drainage tap at the bottom of the reservoir. The other hazardous events resulted in a low degree of risk (Table 5). 
TABLE 2: Chlorine residual, electrical conductivity, and nitrate measurements.

\begin{tabular}{|c|c|c|c|c|c|c|c|c|c|c|c|c|}
\hline \multirow[b]{2}{*}{ Local standard } & \multicolumn{4}{|c|}{ Chlorine residual (mg/liter) } & \multicolumn{4}{|c|}{ Electrical conductivity $(\mu \mathrm{S} / \mathrm{cm})$} & \multicolumn{4}{|c|}{ Nitrate $\mathrm{NO}^{3-}(\mathrm{mg} / \mathrm{L})$} \\
\hline & PWA & & & $0.2-1$ & PWA & & & 250 & PWA & & & 70 \\
\hline $\begin{array}{l}\text { International } \\
\text { standard }\end{array}$ & WHO & & & $0.2-1$ & WHO & & & 250 & WHO & & & 50 \\
\hline DWSS & Mean \pm SD & Min & Max & $\begin{array}{l}\text { Samples } \\
\text { met the } \\
\text { standard } \\
(\%)\end{array}$ & Mean \pm SD & Min & Max & $\begin{array}{l}\text { Samples } \\
\text { met the } \\
\text { standard } \\
(\%)\end{array}$ & Mean \pm SD & Min & Max & $\begin{array}{l}\text { Samples } \\
\text { met the } \\
\text { standard } \\
(\%)\end{array}$ \\
\hline $\begin{array}{l}\text { Catchment } \\
(n=109)\end{array}$ & $0.19 \pm 0.3$ & 0 & 0.9 & 31.2 & $2165.1 \pm 969.8$ & 750 & 5000 & 0 & $180.4 \pm 108.9$ & 35 & 445 & 12.8 \\
\hline $\begin{array}{l}\text { Treatment plant } \\
(n=109)\end{array}$ & $0.09 \pm 0.2$ & 0 & 0.9 & 18.3 & $223.1 \pm 162.6$ & 60 & 1010 & 71.5 & $18.8 \pm 12.9$ & 1.32 & 60 & 100 \\
\hline $\begin{array}{l}\text { Tanker truck } \\
(n=197)\end{array}$ & $0.03 \pm 0.1$ & 0 & 0.9 & 14.7 & $226.4 \pm 187.6$ & 50 & 1200 & 70.7 & $19.9 \pm 12.9$ & 1.32 & 64 & 100 \\
\hline $\begin{array}{l}\text { Desalinated } \\
\text { water at } \\
\text { household } \\
(n=384)\end{array}$ & $0.01 \pm 0.06$ & 0 & 0.3 & 4.3 & $235.4 \pm 186.4$ & 50 & 1300 & 41.9 & $21.9 \pm 13.3$ & 4.91 & 68 & 100 \\
\hline $\begin{array}{l}\text { Municipal water } \\
\text { at household } \\
(n=384)\end{array}$ & $0.19 \pm 0.3$ & 0 & 0.9 & 30.2 & $2000.3 \pm 908.5$ & 750 & 5000 & 0 & $202.6 \pm 11.02$ & 43 & 456 & 8.8 \\
\hline
\end{tabular}

TABLE 3: Assessment of hazardous events at catchments by seven raters.

\begin{tabular}{|c|c|c|c|c|}
\hline Hazard & Hazardous event & $\begin{array}{l}\text { Likelihood avg } \\
\text { (SD) }\end{array}$ & $\begin{array}{l}\text { Severity avg } \\
(\mathrm{SD})\end{array}$ & Risk level avg (SD) \\
\hline Chemical & High level of dissolved salts in water & $4.11(0.65)$ & $3.41(0.58)$ & $\begin{array}{l}14.04(3.26) \text { (high } \\
\text { risk) }\end{array}$ \\
\hline Microbial and chemical & Excessive algal formations in water storage tanks & $2.93(0.52)$ & $3.40(0.66)$ & $\begin{array}{l}10.15 \text { (3.19) (high } \\
\text { risk) }\end{array}$ \\
\hline Microbial & Sewage collection within $200 \mathrm{~m}$ of the borehole & $2.38(0.73)$ & $2.97(0.79)$ & $\begin{array}{c}7.48(3.76) \\
\text { (medium risk) }\end{array}$ \\
\hline Microbial & $\begin{array}{l}\text { Water leakage between water well and water storage } \\
\text { tank }\end{array}$ & $2.54(0.63)$ & $2.82(0.63)$ & $\begin{array}{c}7.41(3.21) \\
\text { (medium risk) }\end{array}$ \\
\hline Microbial & $\begin{array}{l}\text { The leaking water forms stagnant ponding within } 10 \mathrm{~m} \\
\text { of the borehole }\end{array}$ & $2.49(0.74)$ & $2.69(0.75)$ & $\begin{array}{c}7.09(3.50) \\
\text { (medium risk) }\end{array}$ \\
\hline Chemical and microbial & $\begin{array}{l}\text { Spilled water drainage channels are absent or cracked } \\
\text { or unclean }\end{array}$ & $2.40(0.70)$ & $2.67(0.73)$ & $\begin{array}{c}6.77(3.44) \\
\text { (medium risk) }\end{array}$ \\
\hline Microbial & $\begin{array}{l}\text { Human, animals, or birds excreta on the ground } \\
\text { within } 10 \mathrm{~m} \text { of the borehole }\end{array}$ & $2.25(0.66)$ & $2.80(0.75)$ & $\begin{array}{c}6.62(3.29) \\
\text { (medium risk) }\end{array}$ \\
\hline Microbial & $\begin{array}{c}\text { The fence of the water well is inadequate to prevent the } \\
\text { entry of animals }\end{array}$ & $2.36(0.64)$ & $2.68(0.66)$ & $\begin{array}{c}6.61(3.10) \\
\text { (medium risk) }\end{array}$ \\
\hline Chemical & $\begin{array}{l}\text { Accidental spillage of diesel or other chemicals within } \\
\qquad 100 \mathrm{~m} \text { of the borehole }\end{array}$ & $2.33(0.65)$ & $2.68(0.76)$ & $\begin{array}{c}6.60(3.30) \\
\text { (medium risk) }\end{array}$ \\
\hline $\begin{array}{l}\text { Chemical, microbial, and } \\
\text { physical }\end{array}$ & $\begin{array}{c}\text { The cement cap of a borehole is absent, cracked or } \\
\text { unclean }\end{array}$ & $2.33(0.66)$ & $2.57(0.69)$ & $\begin{array}{c}6.29(2.99) \\
\text { (medium risk) }\end{array}$ \\
\hline Chemical and microbial & $\begin{array}{c}\text { The pump house at the point of attachment to the } \\
\text { borehole base is loose }\end{array}$ & $2.28(0.72)$ & $2.53(0.74)$ & $\begin{array}{c}6.16(3.15) \\
\text { (medium risk) }\end{array}$ \\
\hline Chemical and microbial & $\begin{array}{l}\text { Stockbreeding, agricultural activities within } 50 \mathrm{~m} \text { of } \\
\text { the borehole }\end{array}$ & $2.19(0.60)$ & $2.60(0.69)$ & $\begin{array}{l}5.96(2.71)(\text { low } \\
\text { risk) }\end{array}$ \\
\hline Microbial & Rainstorms or floods affect the borehole area & $2.20(0.76)$ & $2.38(0.80)$ & $\begin{array}{c}5.72(3.41)(\text { low } \\
\text { risk })\end{array}$ \\
\hline $\begin{array}{l}\text { Chemical, microbial, and } \\
\text { physical }\end{array}$ & $\begin{array}{l}\text { Waste disposal site or landfill within } 300 \mathrm{~m} \text { of the } \\
\text { borehole }\end{array}$ & $2.07(0.66)$ & $2.29(0.76)$ & $\begin{array}{l}5.15 \text { (2.99) (low } \\
\text { risk) }\end{array}$ \\
\hline
\end{tabular}

Risk level $=$ likelihood $*$ Severity. 
TABLE 4: Assessment of hazardous events at brackish desalination plants by seven raters.

\begin{tabular}{|c|c|c|c|c|}
\hline Hazard & Hazardous event & $\begin{array}{l}\text { Likelihood avg } \\
\text { (SD) }\end{array}$ & $\begin{array}{l}\text { Severity avg } \\
\text { (SD) }\end{array}$ & Risk level avg (SD) \\
\hline Microbial & Low level of disinfection below the recommended limit & $3.27(1.00)$ & $3.60(1.05)$ & $\begin{array}{l}12.71 \text { (6.55) (high } \\
\text { risk) }\end{array}$ \\
\hline $\begin{array}{l}\text { Chemical and } \\
\text { microbial }\end{array}$ & $\begin{array}{l}\text { The power outages affect the efficiency of the desalination } \\
\text { process }\end{array}$ & $3.25(3.23)$ & $2.24(2.23)$ & $\begin{array}{l}10.04(9.99) \text { (high } \\
\text { risk) }\end{array}$ \\
\hline $\begin{array}{l}\text { Chemical and } \\
\text { microbial }\end{array}$ & Desalinated water is mixed with nondesalinated water & $2.49(1.34)$ & $2.49(1.38)$ & $\begin{array}{c}7.95(7.32) \\
\text { (medium risk) }\end{array}$ \\
\hline $\begin{array}{l}\text { Physical, chemical, and } \\
\text { microbial }\end{array}$ & $\begin{array}{l}\text { The cap of the desalinated water tank is absent or partially } \\
\text { opened }\end{array}$ & $1.97(1.07)$ & $2.27(1.28)$ & $\begin{array}{l}5.76(5.79) \text { (low } \\
\text { risk) }\end{array}$ \\
\hline Microbial & $\begin{array}{l}\text { Water discontinuity or stored for an extended period } \\
\text { inside the tank }\end{array}$ & $2.04(0.94)$ & $2.25(1.11)$ & $\begin{array}{l}5.57(4.87) \text { (low } \\
\text { risk) }\end{array}$ \\
\hline $\begin{array}{l}\text { Physical, chemical, and } \\
\text { microbial }\end{array}$ & $\begin{array}{c}\text { Presence of foreign objects inside of desalinated water } \\
\text { storage tank }\end{array}$ & $1.88(0.89)$ & $2.23(1.25)$ & $\begin{array}{l}5.23(4.79) \text { (low } \\
\text { risk) }\end{array}$ \\
\hline Microbial & The discharge pipes and hoses touch the ground & $1.95(1.07)$ & $2.05(1.19)$ & $\begin{array}{l}5.22(5.71)(\text { low } \\
\text { risk) }\end{array}$ \\
\hline Physical and microbial & Air vents unscreened allowing ingress of insects & $2.49(1.07)$ & $1.83(0.75)$ & $\begin{array}{l}5.21(3.90)(\text { low } \\
\text { risk) }\end{array}$ \\
\hline $\begin{array}{l}\text { Chemical, physical, } \\
\text { and microbial }\end{array}$ & $\begin{array}{l}\text { The desalination plant is unlicensed and nonmonitored by } \\
\text { the Ministry of Health }\end{array}$ & $2.01(1.60)$ & $1.60(0.87)$ & $\begin{array}{l}4.54(5.64) \text { (low } \\
\text { risk) }\end{array}$ \\
\hline $\begin{array}{l}\text { Chemical and } \\
\text { microbial }\end{array}$ & $\begin{array}{l}\text { Excessive algal formations in filters due to irregular } \\
\text { backwashing of filters }\end{array}$ & $1.71(1.21)$ & $1.76(1.25)$ & $\begin{array}{l}4.47 \text { (6.46) (low } \\
\text { risk) }\end{array}$ \\
\hline Microbial & $\begin{array}{l}\text { Desalination plant's fence or roof cover inadequate, which } \\
\text { are allowing animals or birds entry }\end{array}$ & $1.72(0.82)$ & $1.91(1.07)$ & $\begin{array}{l}4.11(4.26) \text { (low } \\
\text { risk) }\end{array}$ \\
\hline Chemical & The desalinated water storage tank made of corrosive metal & $1.69(1.50)$ & $1.40(0.90)$ & $\begin{array}{l}3.68(5.90) \text { (low } \\
\text { risk) }\end{array}$ \\
\hline $\begin{array}{l}\text { Chemical and } \\
\text { microbial }\end{array}$ & $\begin{array}{l}\text { Human excreta, sewage collection within } 50 \mathrm{~m} \text { of the } \\
\text { desalinated water storage tanks }\end{array}$ & $1.44(1.14)$ & $1.50(1.27)$ & $\begin{array}{l}3.60(6.76) \text { (low } \\
\text { risk) }\end{array}$ \\
\hline $\begin{array}{l}\text { Chemical, physical, } \\
\text { and microbial }\end{array}$ & The drainage hole at the bottom of the tank is not available & $1.83(1.23)$ & $1.48(0.75)$ & $\begin{array}{l}3.53(4.30) \text { (low } \\
\text { risk) }\end{array}$ \\
\hline Microbial & $\begin{array}{l}\text { There is leakage between desalination points and } \\
\text { desalinated water storage tank }\end{array}$ & $1.71(0.81)$ & $1.68(0.78)$ & $\begin{array}{l}3.42(3.01) \text { (low } \\
\text { risk) }\end{array}$ \\
\hline Microbial & $\begin{array}{l}\text { Spilled water forms stagnant ponding within } 10 \mathrm{~m} \text { of the } \\
\text { desalinated water storage tanks }\end{array}$ & $1.71(0.81)$ & $1.63(0.71)$ & $\begin{array}{l}3.32(2.90) \text { (low } \\
\text { risk) }\end{array}$ \\
\hline Microbial & The desalinated water storage tank made of opaque plastic & $1.42(1.13)$ & $1.41(1.09)$ & $\begin{array}{l}3.23(6.10) \text { (low } \\
\text { risk) }\end{array}$ \\
\hline $\begin{array}{l}\text { Chemical and } \\
\text { microbial }\end{array}$ & $\begin{array}{l}\text { The water storage tank used to store other liquids other } \\
\text { than desalinated water }\end{array}$ & $1.44(0.93)$ & $1.43(0.92)$ & $\begin{array}{l}2.78(4.09)(\text { low } \\
\text { risk) }\end{array}$ \\
\hline Chemical & $\begin{array}{c}\text { Accidental spillage of diesel within } 100 \mathrm{~m} \text { of the desalinated } \\
\text { water storage tanks }\end{array}$ & $1.38(1.07)$ & $1.26(0.73)$ & $\begin{array}{l}2.51(4.53) \text { (low } \\
\text { risk) }\end{array}$ \\
\hline Chemical & Overdosing of treatment chemicals (such as chlorine) & $1.06(0.31)$ & $1.06(0.31)$ & $\begin{array}{l}1.23 \text { (1.17) (low } \\
\text { risk) }\end{array}$ \\
\hline
\end{tabular}

Risk level $=$ likelihood $*$ Severity.

3.2.4. Consumption Points. At households, a very high degree of risk was due to the low level of disinfection. A high degree of risk was because of the excessive algal formations inside the drinking water storage tanks. A medium degree of risk as a result of negligence of the periodic washing of drinking water tanks with chlorine and soap. The other hazardous events led to a low degree of risk (Table 6).

\section{Discussion}

Despite the persistent efforts to overcome the DWSSs problems in the Gaza strip, as in most developing countries, the Gaza strip is still suffering from the presence of water quality challenges.

The results of this study highlighted the most hazardous events in the drinking water supply system in the Gaza strip, which are mainly related to the high levels of groundwater salinity, the low level of disinfection, the growth of biofilm bacteria inside water storage tanks, the effect of electricity outages on the efficiency of the desalination process, and leakage of water from the tanker truck reservoirs. Several studies have been conducted to assess chemical, biological, and physical hazardous events individually in Gaza's water supply systems [29-31]. 
TABLE 5: Assessment of hazardous events in the tanker trucks by seven raters.

\begin{tabular}{|c|c|c|c|c|}
\hline Hazard & Hazardous event & $\begin{array}{l}\text { Likelihood avg } \\
\text { (SD) }\end{array}$ & $\begin{array}{l}\text { Severity avg } \\
\text { (SD) }\end{array}$ & Risk level avg (SD) \\
\hline Microbial & Low level of disinfection below the recommended limit & $3.77(0.80)$ & $3.91(0.85)$ & $\begin{array}{l}15.35(6.01) \text { (very } \\
\text { high risk) }\end{array}$ \\
\hline Chemical and microbial & Excessive algal formations inside the tanker truck tank & $3.23(1.07)$ & $3.43(1.06)$ & $\begin{array}{l}12.13(7.27) \text { (high } \\
\text { risk) }\end{array}$ \\
\hline Microbial & $\begin{array}{l}\text { There is water leakage from the tanker reservoir or its } \\
\text { pipes }\end{array}$ & $3.79(0.83)$ & $2.85(0.39)$ & $\begin{array}{l}10.98 \text { (3.24) (high } \\
\text { risk) }\end{array}$ \\
\hline $\begin{array}{l}\text { Chemical, physical, and } \\
\text { microbial }\end{array}$ & $\begin{array}{c}\text { The tanker truck is unlicensed and nonmonitored by } \\
\text { the Ministry of Health }\end{array}$ & $3.19(0.86)$ & $2.76(0.48)$ & $\begin{array}{l}8.96(3.31) \text { (medium } \\
\text { risk) }\end{array}$ \\
\hline $\begin{array}{l}\text { Chemical, physical, and } \\
\text { microbial }\end{array}$ & $\begin{array}{c}\text { The drainage tap at the bottom of the tank does not } \\
\text { exist }\end{array}$ & $2.86(1.16)$ & $2.35(0.89)$ & $\begin{array}{l}7.59(4.58) \text { (medium } \\
\text { risk) }\end{array}$ \\
\hline Chemical and microbial & Desalinated water is mixed with nondesalinated water & $2.35(0.85)$ & $2.56(1.06)$ & $\begin{array}{l}6.87(4.84) \text { (medium } \\
\text { risk) }\end{array}$ \\
\hline $\begin{array}{l}\text { Chemical, physical, and } \\
\text { microbial }\end{array}$ & Presence of foreign objects inside of tanker truck tank & $2.10(0.87)$ & $2.37(1.08)$ & 5.82 (4.43) (low risk) \\
\hline Microbial & $\begin{array}{l}\text { Water discontinuity or stored for an extended period } \\
\text { inside the tanker truck tank }\end{array}$ & $2.04(0.85)$ & $2.09(0.95)$ & 4.91 (3.97) (low risk) \\
\hline Microbial & The parking garage of the tanker truck not sanitary & $2.24(1.03)$ & $1.84(0.86)$ & 4.87 (4.43) (low risk) \\
\hline Chemical and microbial & $\begin{array}{c}\text { The delivery nozzle, pump, or hoses are dirty or in poor } \\
\text { condition }\end{array}$ & $2.00(0.73)$ & $2.12(0.72)$ & 4.70 (2.88) (low risk) \\
\hline $\begin{array}{l}\text { Chemical, physical, and } \\
\text { microbial }\end{array}$ & The discharge pipes and hoses touch the ground & $2.20(0.91)$ & $1.85(0.82)$ & 4.69 (3.74) (low risk) \\
\hline $\begin{array}{l}\text { Chemical, physical, and } \\
\text { microbial }\end{array}$ & $\begin{array}{c}\text { The cap of the tanker truck tank is absent or partially } \\
\text { opened }\end{array}$ & $1.60(0.83)$ & $1.88(1.14)$ & 3.90 (4.47) (low risk) \\
\hline $\begin{array}{l}\text { Chemical, physical, and } \\
\text { microbial }\end{array}$ & $\begin{array}{l}\text { The tanker truck engine exhaust and road } \\
\text { contaminants affect the water quality }\end{array}$ & $1.62(0.86)$ & $1.80(1.05)$ & 3.75 (4.33) (low risk) \\
\hline $\begin{array}{l}\text { Chemical, physical, and } \\
\text { microbial }\end{array}$ & $\begin{array}{c}\text { The overflow pipe is unclean or without protective } \\
\text { mesh }\end{array}$ & $1.68(0.94)$ & $1.67(0.85)$ & 3.47 (3.35) (low risk) \\
\hline Chemical & $\begin{array}{c}\text { The tanker truck desalinated water storage tank made } \\
\text { of corrosive metal }\end{array}$ & $1.53(1.12)$ & $1.49(1.05)$ & 3.44 (5.26) (low risk) \\
\hline Chemical and microbial & $\begin{array}{l}\text { The tanker truck tank used to store other liquids other } \\
\text { than desalinated water }\end{array}$ & $1.56(0.65)$ & $1.31(0.57)$ & 2.31 (2.07) (low risk) \\
\hline Microbial & $\begin{array}{c}\text { The tanker truck desalinated water storage tank made } \\
\text { of opaque plastic }\end{array}$ & $1.20(0.74)$ & $1.13(0.50)$ & $1.72(2.73)$ (low risk) \\
\hline Chemical & $\begin{array}{l}\text { A high level of overdosing of treatment chemicals (such } \\
\text { as chlorine) }\end{array}$ & $1.08(0.26)$ & $1.03(0.17)$ & 1.14 (0.55) (low risk) \\
\hline
\end{tabular}

Risk level $=$ likelihood $*$ Severity.

The high level of aquifer salinity was attributable to the mobilization of deep brines and seawater intrusion due to overabstraction of groundwater [32-34]. Several recommendations were proposed by Abbas et al. and Abuzerr et al. aimed to improve the quality of groundwater as well as the areas surrounding the water wells $[35,36]$.

Because we noticed that water desalination plants apply chlorination before the desalination process, not after, preceding reports have proven a significant correlation between the prevalence of waterborne diseases and inadequate chlorination of drinking water in Gaza [18, 37-39]. Moreover, Sadallah and Al-Najar study showed a significant association between the high incidence of diarrheal diseases among the population of Um Al Nasser village and the low level of residual chlorine in drinking water networks [29].

The results of our study also showed a gradual decrease in residual chlorine levels with the progress in DWSS parts, starting from the source point and ending with consumption point at household. We can state that Gaza's DWSS, in general, suffered from inadequate disinfection, which increases the risk of biofilm formation and increases the chance of bacteria regrowth [40]. These outcomes are consistent with Aish, 2013 findings, which revealed an increase in microbiological contamination level throughout Gaza's DWSSs [30]. It is worth mentioning that we have noticed that many desalination plants were applying chlorination before the desalination process and not after. Also, the owners of brackish desalination plants do not add sufficient amounts of chlorine to the desalinated water due to aesthetical issues such as odor and taste issues because they claim that Gazans do not like the taste of chlorine in drinking water, so they try to keep their customers satisfied. Nevertheless, in order to protect the public and to ensure the safety of DWSSs, the PWA has 
TABLE 6: Assessment of hazardous events in the drinking water at houses by seven raters.

\begin{tabular}{|c|c|c|c|c|}
\hline Hazard & Hazardous event & $\begin{array}{l}\text { Likelihood avg } \\
\text { (SD) }\end{array}$ & $\begin{array}{l}\text { Severity avg } \\
\text { (SD) }\end{array}$ & Risk level avg (SD) \\
\hline Microbial & Low level of disinfection below the recommended limit & $3.87(0.98)$ & $4.02(0.92)$ & $\begin{array}{l}16.38(6.93) \text { (very } \\
\text { high risk) }\end{array}$ \\
\hline $\begin{array}{l}\text { Chemical and } \\
\text { microbial }\end{array}$ & $\begin{array}{l}\text { Excessive algal formations inside of desalinated water } \\
\text { storage tank }\end{array}$ & $3.62(1.05)$ & $3.82(1.07)$ & $\begin{array}{l}14.82(6.96) \text { (high } \\
\text { risk) }\end{array}$ \\
\hline Microbial & $\begin{array}{l}\text { The drinking water tank is not periodically washed with } \\
\text { chlorine and soap }\end{array}$ & $2.07(1.25)$ & $2.32(1.42)$ & $\begin{array}{c}6.48(7.24) \\
(\text { medium risk) }\end{array}$ \\
\hline $\begin{array}{l}\text { Chemical, physical, } \\
\text { and microbial }\end{array}$ & $\begin{array}{c}\text { Hand washing is not practiced before filling the drinking } \\
\text { water storage tank }\end{array}$ & $2.33(1.25)$ & $1.74(0.78)$ & $\begin{array}{l}4.91(4.47) \text { (low } \\
\text { risk) }\end{array}$ \\
\hline Microbial & The desalinated water storage tank made of opaque plastic & $2.27(1.37)$ & $1.47(0.68)$ & $\begin{array}{l}4.15 \text { ( } 4.34) \text { (low } \\
\text { risk) }\end{array}$ \\
\hline Microbial & $\begin{array}{l}\text { Water discontinuity or stored for an extended period } \\
\text { inside the desalinated water storage tank }\end{array}$ & $2.27(0.88)$ & $1.47(0.70)$ & $\begin{array}{l}3.74(3.18)(\text { low } \\
\text { risk) }\end{array}$ \\
\hline Microbial & $\begin{array}{l}\text { The area around drinking water storage tank is unclean } \\
\text { and has an animal or birds access }\end{array}$ & $1.39(0.93)$ & $1.56(2.23)$ & $\begin{array}{l}3.28(5.51)(\text { low } \\
\text { risk) }\end{array}$ \\
\hline Chemical & $\begin{array}{l}\text { The desalinated water storage tank made of corrosive } \\
\text { metal }\end{array}$ & $1.37(0.92)$ & $1.51(1.23)$ & $\begin{array}{l}3.17(5.49) \text { (low } \\
\text { risk) }\end{array}$ \\
\hline $\begin{array}{l}\text { Chemical and } \\
\text { microbial }\end{array}$ & Desalinated water is mixed with nondesalinated water & $1.46(0.80)$ & $1.58(1.01)$ & $\begin{array}{l}3.08(4.02) \text { (low } \\
\text { risk) }\end{array}$ \\
\hline Microbial & Drinking water storage tank is sited close to a toilet & $1.33(0.89)$ & $1.42(1.10)$ & $\begin{array}{l}2.85(5.28) \text { (low } \\
\text { risk) }\end{array}$ \\
\hline $\begin{array}{l}\text { Chemical, physical, } \\
\text { and microbial }\end{array}$ & $\begin{array}{c}\text { Presence of foreign objects inside of desalinated water } \\
\text { storage tank }\end{array}$ & $1.38(0.73)$ & $1.50(0.95)$ & $\begin{array}{l}2.74(3.65)(\text { low } \\
\text { risk) }\end{array}$ \\
\hline $\begin{array}{l}\text { Chemical, physical, } \\
\text { and microbial }\end{array}$ & $\begin{array}{l}\text { The cap of the desalinated water tank is absent or partially } \\
\text { opened }\end{array}$ & $1.38(0.73)$ & $1.46(0.86)$ & $\begin{array}{l}2.61(3.34)(\text { low } \\
\text { risk) }\end{array}$ \\
\hline Microbial & $\begin{array}{c}\text { Children get drinking water directly from the tank tap by } \\
\text { their mouths }\end{array}$ & $1.30(0.88)$ & $1.31(0.89)$ & $\begin{array}{l}2.46(4.70) \text { (low } \\
\text { risk) }\end{array}$ \\
\hline Microbial & The drinking water storage tank is leaking & $1.19(0.67)$ & $1.25(0.83)$ & $\begin{array}{l}2.03(3.74)(\text { low } \\
\text { risk) }\end{array}$ \\
\hline Microbial & The drinking water storage container sited at ground level & $1.20(0.74)$ & $1.15(0.58)$ & $\begin{array}{l}1.80(3.23) \text { (low } \\
\text { risk) }\end{array}$ \\
\hline Microbial & $\begin{array}{l}\text { Spilled water accumulates around the drinking water } \\
\text { storage tank }\end{array}$ & $1.18(0.65)$ & $1.14(0.49)$ & $\begin{array}{l}1.66(2.47) \text { (low } \\
\text { risk) }\end{array}$ \\
\hline $\begin{array}{l}\text { Chemical and } \\
\text { microbial }\end{array}$ & $\begin{array}{l}\text { The water storage tank used to store other liquids other } \\
\text { than desalinated water }\end{array}$ & $1.09(0.46)$ & $1.14(0.70)$ & $\begin{array}{l}1.56(2.86)(\text { low } \\
\text { risk) }\end{array}$ \\
\hline Chemical & $\begin{array}{c}\text { A high level of overdosing of treatment chemicals (such as } \\
\text { chlorine) }\end{array}$ & $1.01(0.09)$ & $1.01(0.12)$ & $\begin{array}{l}1.03(0.27) \text { (low } \\
\text { risk) }\end{array}$ \\
\hline
\end{tabular}

Risk level $=$ likelihood $*$ Severity

adopted the WHO chlorine residual limit as a national standard [41]. Accordingly, constant monitoring of chlorine residual level in public drinking water supply systems is crucial [42-44].

Surprisingly, we found an increase in the electrical conductivity level in the desalinated water at desalination plants in comparison with the desalinated water at households (Table 2).

This could probably be attributed to the erroneous practices of mixing the nonimproved water with desalinated water. Moreover, from our point of view, the corrupt practices of waters mixing at desalination plants and tanker trucks mainly takes place due to shortage of electricity supplies in the Gaza strip. This situation prevents the operation of desalination plants for more than 8 hours a day, thereby compelling the owners of desalination plants and tanker trucks to mix the waters in order to meet customers' demands. Waters mixing at the household might happen because of the inability of a household to procure desalinated water. Accordingly, the introduction of a cross-subsidy technique to support poor households that cannot afford the WHO limit of 3 New Israeli Shekel per cubic meter $\left(\mathrm{NIS} / \mathrm{m}^{3}\right)$ ( 1 USD $\approx 3.5$ NIS). Besides, seeking sustainable cost-effective energy alternatives to increase the efficiency of the desalination plants is highly recommended $[45,46]$. The high levels of nitrate ions we found in this study are consistent with the previous investigations carried out in the Gaza strip that linked its source to improper wastewater disposal and overuse of chemical fertilizers in the agricultural activities $[32,47]$. 


\section{Conclusion and Recommendation}

In this study, the prioritization of hazardous events in DWSSs according to their degree of risk was carried out to decide on the best risk-reduction strategies. This study demonstrated the inadequacy of chlorination in Gaza's DWSSs. The risk levels of hazardous events were ranged from low to very high. The highest levels of risks were related to the high salinity level of groundwater, the low level of disinfection, the formation of biofilm bacteria inside of drinking water storage tanks, the effect of electricity outages on the efficiency of the desalination process, and leakage of water from the tanker truck reservoir. Surprisingly, we found an increase in the electrical conductivity level in the desalinated water at desalination plants in comparison with the desalinated water at households. This was attributed to the unfortunate practice of mixing the nonimproved water with desalinated water. High levels of nitrate were found in the DWSSs, indicating sever health impacts on the public. Therefore, in view of these findings, we recommend further efforts and application of more control measures to reduce the risk of hazardous events on DWSSs as well as to provide safe drinking water for the community following the Palestinian water authority guidelines.

\section{Abbreviations}

DWSSs: Drinking water supply systems

WHO: World health organization

WSP: Water safety plan

DALYs: Disability-adjusted life years

GDWQ: Guidelines for drinking water quality.

\section{Data Availability}

The data used to support the findings of this study are available from the corresponding author upon request.

\section{Conflicts of Interest}

The authors declare that there are no conflicts of interest regarding the publication of this paper.

\section{Authors' Contributions}

$\mathrm{SA}, \mathrm{KZ}$, and $\mathrm{MH}$ participated in idea conception, proposal development, design of the study, and data collection. RN and SHM performed the statistical analysis and drafted the manuscript. SN and MY supervising the study and participated in the draft review. All authors have participated in preparing and offering the training course. All authors have read and approved the final version of the manuscript and agree with the order of the presentation of the authors.

\section{Acknowledgments}

The authors are grateful to the owners of the water desalination plants, tanker trucks, and households in the Gaza strip and the WSP team members for their valuable participation in this study. The authors also wish to thank the
Tehran University of Medical Sciences, International campus, the Palestinian Ministry of Health, and Palestinian water authority for supporting the implementation of the present work. The authors express their sincere gratitude to the Palestine-Québec Science Bridge for their facilitations to carry out this work. Finally, their appreciation goes to Dr. Waliu Jawula Salisu for his immense contribution in improving the readability of this article.

\section{References}

[1] J. Bartram, Water Safety Plan Manual: Step-by-Step Risk Management for Drinking-Water Suppliers, World Health Organization, Geneva, Switzerland, 2009.

[2] WHO, Guidelines for Drinking-Water Quality: Recommendations, Vol. 1, World Health Organization, Geneva, Switzerland, 2004.

[3] WHO, "Guidelines for drinking-water quality. Vol. 2, health criteria and other supporting information: addendum," World Health Organization, Geneva, Switzerland, 1998.

[4] M. J. Gunnarsdottir, S. M. Gardarsson, M. Elliott, G. Sigmundsdottir, and J. Bartram, "Benefits of water safety plans: microbiology, compliance, and public health," Environmental Science \& Technology, vol. 46, no. 14, pp. 7782-7789, 2012.

[5] C. Summerill, S. J. T. Pollard, and J. A. Smith, "The role of organizational culture and leadership in water safety plan implementation for improved risk management," Science of the Total Environment, vol. 408, no. 20, pp. 4319-4327, 2010.

[6] A. Nijhawan, P. Jain, A. Sargaonkar, and P. K. Labhasetwar, "Implementation of water safety plan for a large-piped water supply system," Environmental Monitoring and Assessment, vol. 186, no. 9, pp. 5547-5560, 2014.

[7] S. E. Hrudey, E. J. Hrudey, and S. J. T. Pollard, "Risk management for assuring safe drinking water," Environment International, vol. 32, no. 8, pp. 948-957, 2006.

[8] F. Sun, J. Chen, Q. Tong, and S. Zeng, "Integrated risk assessment and screening analysis of drinking water safety of a conventional water supply system," Water Science and Technology, vol. 56, no. 6, pp. 47-56, 2007.

[9] Y. Y. Omar, A. Parker, J. A. Smith, and S. J. T. Pollard, "Risk management for drinking water safety in low and middle income countries-cultural influences on water safety plan (WSP) implementation in urban water utilities," Science of the Total Environment, vol. 576, pp. 895-906, 2017.

[10] C. Collivignarelli, "Water safety: one of the primary objectives of our time," Ambiente e Agua-An Interdisciplinary Journal of Applied Science, vol. 12, no. 1, pp. 1-7, 2017.

[11] WHO, A Road Map to Support Country-Level Implementation of Water Safety Plans, World Health Organization, Geneva, Switzerland, 2010.

[12] WHO, European Strategic Workshop on Water Safety Planning Berlin. Germany: Key Outcomes, World Health Organization, International Water Association, Geneva, Switzerland, 2014.

[13] G. O. Oluwasanya and R. C. Carter, "Water safety planning for small water supply systems: the framework and control measures," Water Science and Technology: Water Supply, vol. 17, no. 6, pp. 1524-1533, 2017.

[14] A. Eslami, M. Ghaffari, B. Barikbin, and F. Fanaei, "Assessment of safety in drinking water supply system of Birjand city using World Health Organization's water safety plan," Environmental Health Engineering and Management Journal, vol. 5, no. 1, pp. 39-47, 2018. 
[15] G. Duressa, F. Assefa, and M. Jida, "Assessment of bacteriological and physicochemical quality of drinking water from source to household tap connection in Nekemte, Oromia, Ethiopia," Journal of Environmental and Public Health, vol. 2019, Article ID 2129792, 7 pages, 2019.

[16] D. S. M. Deere, A. Davison, G. Helm, and A. Dufour, "Management strategies," in Water Quality: Guidelines, Standards and Health-Assessment of Risk and Risk Management for Water-Related Infectious Disease, pp. 257-288, World Health Organization, Geneva, Switzerland, 2001.

[17] G. Stoneburner, A. Y. Goguen, and A. Feringa, Sp 800-30. Risk Management Guide for Information Technology Systems, U.S. Department of Commerce, National Institute of Standards and Technology, Gaithersburg, MD, USA, 2002.

[18] S. A. Amr and M. M. Yassin, "Microbial contamination of the drinking water distribution system and its impact on human health in Khan Yunis Governorate, Gaza Strip: seven years of monitoring (2000-2006)," Public Health, vol. 122, no. 11, pp. 1275-1283, 2008.

[19] E. MacDonald, B. Herrador, S. Hyllestad et al., "Water usage in the Gaza Strip: recommendations from a literature review and consultations with experts," Eastern Mediterranean Health Journal, vol. 22, no. 12, pp. 910-918, 2016.

[20] PWA: GAZA STRIP, Desalination Facility Project: Necessity, Politics and Energy, Palestinian Water Authority, Gaza, Palestine, 2015.

[21] S. Abuzerr, S. Nasseri, M. Yunesian et al., "Household drinking water safety among the population of Gaza Strip, Palestine: knowledge, attitudes, practices, and satisfaction," Journal of Water, Sanitation and Hygiene for Development, vol. 9, no. 3, pp. 500-512, 2019.

[22] S. Abuzerr, S. Nasseri, M. Yunesian et al., "Prevalence of diarrheal illness and healthcare-seeking behavior by agegroup and sex among the population of Gaza strip: a community-based cross-sectional study," BMC Public Health, vol. 19, no. 1, p. 704, 2019.

[23] J. Bohannon, "Running out of water-and time," Science, vol. 313, 2006.

[24] PCBS: Statistic Brief in the International Population Day, Ramallah-Palestine. Palestinian Central Bureau of Statistics, Palestinian Water Authority, Gaza, Palestine, 2017.

[25] Drinking Water Safety Plan Training Course: This Training Is Sponsored by Alberta Environment and Sustainable Resource Development, https://environment.extranet.gov.ab.ca/info/ 8691.pdf.

[26] APHA, Standard Methods for the Examination of Water and Wastewater: American Public Health Association, American Water Works Association, Denver, CO, USA, 1989.

[27] Aquaread, Instruction Manual for the Aquaprobe AP-2000, Aquaread, Broadstairs, England, 2012, http://www.aquaread. co.uk/downloads/manuals/Aquare_ad-AP2000-AquaprobeManual.pdf.

[28] WHO, Quantitative Microbial Risk Assessment: Application for Water Safety Management, World Health Organization, Geneva, Switzerland, 2016.

[29] H. Sadallah and H. Al-Najar, "Disinfection of intermitted water supply system and its health impact: Um Al Nasser village as a case study," World, vol. 3, no. 2, pp. 32-39, 2015.

[30] A. M. Aish, "Drinking water quality assessment of the middle governorate in the Gaza strip, Palestine," Water Resources and Industry, vol. 4, pp. 13-20, 2013.

[31] A. M. Aish, "Water quality evaluation of small scale desalination plants in the Gaza Strip, Palestine," Desalination and Water Treatment, vol. 29, no. 1-3, pp. 164-173, 2011.
[32] B. Shomar, "Groundwater of the Gaza strip: is it drinkable?" Environmental Geology, vol. 50, no. 5, pp. 743-751, 2006.

[33] S. M. Ghabayen, M. McKee, and M. Kemblowski, "Ionic and isotopic ratios for identification of salinity sources and missing data in the Gaza aquifer," Journal of Hydrology, vol. 318, no. 1-4, pp. 360-373, 2006.

[34] B. Shomar, G. Müller, and A. Yahya, "Potential use of treated wastewater and sludge in the agricultural sector of the Gaza Strip," Clean Technologies and Environmental Policy, vol. 6, no. 2, pp. 128-137, 2004.

[35] M. Abbas, M. Barbieri, M. Battistel, G. Brattini, A. Garone, and B. Parisse, "Water quality in the Gaza Strip: the present scenario," Journal of Water Resource and Protection, vol. 5, no. 1, pp. 54-63, 2013.

[36] S. Abuzerr, S. Nasseri, M. Yunesian et al., "Microbiological quality of drinking water and prevalence of waterborne diseases in the Gaza strip, Palestine: a narrative review," Journal of Geoscience and Environment Protection, vol. 7, no. 4, pp. 122-138, 2019.

[37] M. M. Yassin, S. S. A. Amr, and H. M. Al-Najar, "Assessment of microbiological water quality and its relation to human health in Gaza Governorate, Gaza Strip," Public Health, vol. 120, no. 12, pp. 1177-1187, 2006.

[38] Y. S. A. Mayla and S. S. A. Amr, "Chemical and microbiological quality of drinking water in Gaza Strip, Palestine," Cell, vol. 970, no. 599, Article ID 832708, 2010.

[39] S. Abuzerr, S. Nasseri, M. Yunesian et al., "Water, sanitation, and hygiene risk factors of acute diarrhea among under-five children in the Gaza Strip," Journal of Water, Sanitation and Hygiene for Development, 2019, https://iwaponline.com/ washdev/article/doi/10.2166/washdev.2019.072/71315/Watersanitation-and-hygiene-risk-factors-of-acute.

[40] R. S. Roeder, J. Lenz, P. Tarne, J. Gebel, M. Exner, and U. Szewzyk, "Long-term effects of disinfectants on the community composition of drinking water biofilms," International Journal of Hygiene and Environmental Health, vol. 213, no. 3, pp. 183-189, 2010.

[41] WHO, Guidelines for Drinking-Water Quality, World Health Organization, vol. 38, no. 4, Geneva, Switzerland, 2011.

[42] T. Alia, "A study of free chlorine residual in the drinking water distribution system: Al-ramil al-shimali quarter-lattakia city," Tishreen University Journal for Studies and Scientific Research-Engineering Science Series, vol. 29, no. 2, 2007.

[43] K. Khleifat, M. Abboud, W. Al-Shamayleh, A. Jiries, and K. Tarawneh, "Effect of chlorination treatment on gram negative bacterial composition of recycled wastewater," Pakistan Journal of Biological Sciences, vol. 9, no. 9, pp. 1660-1668, 2006.

[44] WCC, Drinking Water Chlorination, World Chlorine Council, 2008, https://worldchlorine.org/wp-content/ themes/brickthemewp/pdfs/WCC_Policy_Paper_Water_ Chlorination.pdf.

[45] Y. Al-Ghuraiz and A. Enshassi, "Ability and willingness to pay for water supply service in the Gaza Strip," Building and Environment, vol. 40, no. 8, pp. 1093-1102, 2005.

[46] H. Baalousha, "Desalination status in the Gaza Strip and its environmental impact," Desalination, vol. 196, no. 1-3, pp. 1-12, 2006.

[47] B. Shomar, K. Osenbrück, and A. Yahya, "Elevated nitrate levels in the groundwater of the Gaza Strip: distribution and sources," Science of the Total Environment, vol. 398, no. 1-3, pp. 164-174, 2008. 